\title{
CULTURAL HERITAGE INSTITUTIONS DURING AND AFTER THE PANDEMIC- THE COPYRIGHT PERSPECTIVE
}

\author{
Romana Matanovac Vučković, PhD, Associate Professor \\ Faculty of Law, University of Zagreb \\ Trg Republike Hrvatske 14, Croatia \\ romana.matanovac.vuckovic@pravo.hr
}

Ivana Kanceljak, PhD, Assistant Professor

Faculty of Law, University of Zagreb

Trg Republike Hrvatske 14, Croatia

ivana.kanceljak@pravo.hr

\section{Marko Jurić, PhD, Assistant Professor}

Faculty of Law, University of Zagreb

Trg Republike Hrvatske 14, Croatia

marko.juric@pravo.hr

\section{ABSTRACT}

The COVID-19 pandemic has imploded the traditional ways in which creative, cultural and artistic content are presented and consumed. Museums, libraries, archives, and other cultural institutions have been closed in lockdowns all around the European Union, and their content presented and consumed online. This paper will analyse how copyright rules affect cultural heritage institutions (publicly accessible libraries or museums, archives or film or audio heritage institutions) in the digital age. Four recent legal documents at the European level refer to the digitalisation of their collections and the digitised content's exposure to the public in the Digital Single Market. These are Directive 2001/29/EC, Directive 2012/28/EU, Directive (EU) 2019/790 and Directive (EU) 2019/1024.

This paper willfirst analyse how exclusive rights are regulated for authors, other creators, publishers, and producers in the digital age. Those rights need to be respected and exercised effectively by their owners. On the other hand, there is also a public interest, in that digitisation and access to digitised content should be free in cultural heritage institutions. To resolve the tension inherent in this relationship is not easy. The recent rapid change in consumption of creative, cultural and artistic content in the Single Digital Market (due to the pandemic 
caused by the COVID-19 virus) has triggered the need for swifter digitisation of cultural heritage institutions' collections. The European legal framework offers some solutions to this need, which will be presented here. It does not resolve the situation generally, but refers to particular issues, such as orphan works, out-of-commerce works, text and data mining and the re-use of public sector information. In general, copyright protection prevails. Nevertheless, the tendencies towards free access grow stronger every day. This paper will analyse how these four directives interact with each other in the effort to resolve the tension between copyright, digitisation and free access to digitised content in cultural heritage institutions. At the end, two ideas for a new balance are presented.

Keywords: copyright, cultural heritage institutions, orphan works, out-of-commerce works, text and data mining, re-use of public sector information

\section{INTRODUCTION}

The Digital Single Market's functioning is made complex and layered by a multitude of conflicting and interacting interests. This paper will analyse the protection of copyright and related rights with respect to cultural heritage institutions in the European Union, during and after the pandemic. The protection of copyright and related rights may conflict with those institutions' basic mission: preserving their collections and making them accessible to the public.

The transition from traditional to digital is particularly challenging for cultural heritage institutions. ${ }^{1}$ They usually keep material specimens of copyright works in their collections, such as books, photographs, phonograms, videograms, paintings and sculptures. In traditional circumstances, the tension between the public functions of cultural heritage institutions and copyright and related rights has always been resolved by the exclusive right of distribution, and public lending right $^{2}$ as its component. Public lending right - either as an exclusive right or as a right to remuneration ${ }^{3}$ exercised collectively, usually with extended effect - is the

1 See for example Commission Recommendation of 24 August 2006 on the digitisation and online accessibility of cultural material and digital preservation (2006/585/EC).

2 The Court of Justice of the European Union ruled that "lending of a digital copy of a book, where that lending is carried out by placing that copy on the server of a public library and allowing a user to reproduce that copy by downloading it onto his own computer, bearing in mind that only one copy may be downloaded during the lending period and that, after that period has expired, the downloaded copy can no longer be used by that user." See: Case C-174/15 Vereniging Openbare Bibliotheken [2016] ECLI:EU:C:2016:856. Nevertheless, it is emphasised by some authors that e-lending includes a making available to the public right and not a distribution and public lending right. See in detail: Dusollier, S., A manifesto for an e-lending limitation in copyright, JIPITEC - Journal of Intellectual Property, Information Technology and E-Commerce Law, Vol. 5, No. 3, 2014, pp. 1-23.

3 According to Art. 3 para 1 of European Parliament and Council Directive 2006/115/EC on rental right and lending right and on certain rights related to copyright in the field of intellectual property [2006] OJ L 376/28 (hereinafter: Directive 2006/115/EC) authors, performers, phonogram producers 
balanced way to ensure the right owners remain compensated and the mission of cultural heritage institutions accomplished. Concerning exhibitions in museums and similar institutions, the authors usually enjoy the exclusive right of exhibition or public presentation as a special way of communication to the public. In some national legislations, this right is particularly regulated. ${ }^{4}$ Nevertheless, in a sales contract or lending contract with a museum or similar institution, it is implied that licence for the exhibition of the work of visual art is given. For reasons of legal certainty, some national laws regulate that the author of an undisclosed work of visual art, applied art, industrial design, or photographic work implicitly licences public exhibition of the respective work in the sales contract unless agreed otherwise in writing. However, if the work is sold to the museum, gallery or other similar public institution, reservation of the exhibition right is not allowed. ${ }^{5}$

The process of digitisation brings to light new tensions in relations between copyright and related rights owners and cultural heritage institutions. Digitisation includes the exclusive right of reproduction. If digitised content is made available to the public on demand, the exclusive right of communication to the public shall also be involved, particularly the exclusive right of making available to the public. The employment of all these exclusive rights opposes the interests of the copyright and related rights owners, particularly publishers. In traditional circumstances, the usual business models of distributing material copies of protected copyright works and other subject matter were not particularly undermined by cultural heritage institutions' activity. In the digital world, the possibility of accessing the digitised collections of cultural heritage institutions from any place and at any time in most circumstances undermines to a greater extent both copyright and related rights owners' legal interests. This challenging conflicting situation is constantly under discussion. The European Union is trying to offer a new balance for its resolution through several directives that partly refer to this matter.

The COVID-19 pandemic has aggrevated the situation by imploding traditional ways in which creative, cultural and artistic content is presented and consumed.

and film producers are given exclusive rights to authorise or prohibit rental and lending. In Art. 6 of the same directive it is envisaged that Member States will have the option to derogate from the exclusive right for public lending and transform it into a right to remuneration.

4 For example, according to Art. 18 of the German Copyright and Related Rights Act (Urheberrechtsgesetz vom 9. September 1965 (BGBl. I S. 1273), das zuletzt durch Artikel 4 des Gesetzes vom 26. November 2020 (BGBl. I S. 2568) geändert worden ist (Zuletzt geändert durch Art. 4 G v. 26.11.2020 I 2568), [https://www.gesetze-im-internet.de/urhg/index.html\#BJNR012730965BJNE022614360], Accessed 02 April 2021, the exhibition right right to publicly show the original or copies of an unpublished work of the visual arts or the photographic work.

5 For example, see Art. 40 of the Croatian Copyright and Related Rights Act, Official Gazette No. $167 / 03,79 / 07,80 / 11,125 / 11,141 / 13,127 / 14,62 / 17,96 / 18$. 
Museums, libraries, archives, and other cultural heritage institutions have been closed in lockdowns or under restricted access all around the European Union (and the whole world), and their content presented and consumed online. ${ }^{6}$ The challenge to copyright and related rights has grown more rapidly than might have been envisaged. The technology that enables the presentation of cultural heritage online is quickly developing. The European Union's approach has been to gradually and progressively resolve the relationship between cultural heritage institutions' public mission and copyright and related rights by relaxing the existing legal framework to facilitate the mass digitisation and online presentation of collections belonging to cultural heritage institutions. Now, it seems that the process of digitalisation needs to develop more swiftly.

This paper will first analyse how exclusive rights are regulated for authors and other right owners in the digital age. Those rights need to be respected and exercised effectively. On the other hand, there is also a public interest, in that that the collections of cultural heritage institutions are digitised and made widely available to the public. In this respect, the European legal framework will be analysed from the perspective of exemptions and limitations to copyright and related rights. Nevertheless, the European legal framework does not resolve the situation generally. It refers to particular issues, such as orphan works, out-of-commerce works, the preservation of cultural heritage, text and data mining and the re-use of public sector information. In general, copyright protection prevails. The impetus towards free access grow stronger every day. It is to be expected that there will be further relaxation of the copyright and related rights legal framework concerning cultural heritage institutions. However, there is still no such concrete and formal legal initiative. Meanwhile, the public's demands and interests are growing, particularly concerning extreme situations such as the threat to public health in the pandemic situation. Therefore, some new ideas will be presented here.

\section{EXCLUSIVE COPYRIGHT AND RELATED RIGHTS}

Copyright and related rights are exclusive rights. This means that the author or other right owner is entitled to allow or to forbid the use of the work or other subject matter and decide under which circumstances he shall issue a licence. The absolute nature of copyright and related rights obliges all other individuals

For the influence of the COVID-19 crisis on cultural heritage institutions in numbers see: Europa Nostra: COVID-19 \& BEYOND, Challenges and Opportunities for Cultural Heritage, October 2020 [https://www.europanostra.org/wp-content/uploads/2020/10/20201014_COVID19_Consultation-Paper_EN.pdf ], Accessed: 31 March 2021; UNESCO: Culture \& Covid-19, Impact and Response Tracker - special issue, 3 July 2020 [https://en.unesco.org/sites/default/files/special_issue_en_ culture_covid-19_tracker.pdf], Accessed 31 March 2021. 
to refrain from using copyright work or other subject matter in ways defined by the content of the exclusive right. This content is regulated at international and European level, particularly concerning the digital environment. The adaptation of copyright and related rights protection to the digital age began with the WIPO Internet treaties of 1996. It spread to the European level with Directive 2001/29/ EZ $^{8}$ and was recently modernised through Directive (EU) 2019/7909. For the digital environment, particularly interesting are the exclusive right of reproduction, communication to the public, and making available to the public.

Reproduction right was developed so that any reproduction, whatsoever, on any media, in any way, by any technology, direct or indirect, temporary or permanent, is covered by the exclusive right for authors, performers, phonogram producers, film producers and broadcasting organisations. ${ }^{10}$ Communication to the public is not defined in detail. It is regulated so that the authors enjoy the exclusive right of communication to the public "in any way". Simultaneously, there is no definition of what is meant by "communication" except for stating that the communication may appear by wired or wireless means. ${ }^{11}$ Also, there is no definition of what exactly "public" means. "Any" communication to the public is usually not regulated

7 These are the WIPO Copyright Treaty (WCT) (1996) [https://www.wipo.int/treaties/en/ip/wct ] (Accessed: 31 March 2021) and WIPO Performances and Phonograms Treaty (WPPT) (1996) [https:// www.wipo.int/treaties/en/ip/wppt/ ], Accessed 31 March 2021.

8 Council Directive 2001/29/EC on the harmonisation of certain aspects of copyright and related rights in the information society [2001] OJ L 167/10 (hereinafter: Directive 2001/29/EZ).

9 European Parliament and Council Directive 2019/790 on copyright and related rights in the Digital Single Market and amending Directives 96/9/EC and 2001/29/EC [2019] OJ L 130/92 (hereinafter:Directive (EU) 2019/790).

10 The definition of reproduction right is regulated in Art. 2 of Directive 2001/29/EC as the exclusive right for authors, performers, phonogram producers, film producers and broadcasting organisations with respect to the objects of their rights. It is also regulated as an exclusive right in Art. 7 of WPPT for performers and in Art. 11 of WPPT for phonogram producers. Art. 1 of WCT regulates that the contracting parties shall comply with Arts. 1 to 21 of the Berne Convention where exclusive reproduction right is regulated in Art. 9.

11 The provision that "communication" may appear either by wired or wireless means is regulated in Art. 8 of WCT and in Art. 3 para 1 of Directive 2001/29, for authors. Communication to the public has been interpreted in many cases by the Court of Justice of the European Union. See for example: Leistner, M., Copyright at the interface between EU law and national law: definition of "work" and "right of communication to the public, Journal of Intellectual Property Law \& Practice, Vol. 10, No. 8, 2015, pp. 630-635; Quintais, J. P., Untangling the hyperlinking web: In search of the online right of communication to the public, The Journal of World Intellectual Property, Vol. 21, Issue 5-6, 2018, pp. 385-420.

12 Therefore, the Court of Justice of the European Union, with respect to several individual cases, interpreted what "public" means in the internet. This extensive jurisprudence triggered appreciations and criticism at the same time. See: Xalabarder, R., The Role of the CJEU in Harmonizing EU Copyright Law, IIC - International Review of Intellectual Property and Competition Law volume 47, 2016, pp. 635-639. 
as an exclusive right for performers and phonogram producers but only as a right to remuneration with respect to commercial phonograms. ${ }^{13}$

A new exclusive right was developed for interactive uses on the internet through the WIPO Internet Treaties and Directive 2001/29/EC. It is called the right of making available to the public and is considered a special way of communication to the public. The owners of copyright and related rights may authorise or prohibit members of the public from accessing protected content from a place and at a time individually chosen by them. ${ }^{14}$

The right of communication to the public was regulated in more detail in Directive (EU) 2019/790. ${ }^{15}$ An online content-sharing provider performs an act of communication to the public or making available to the public when it gives the public access to works and other subject matter uploaded by its users who are not acting on a commercial basis. This explains, in particular, situations where online content-sharing providers have invoked the so-called "safe harbour provisions" from Directive 2000/31/EC ${ }^{16}$ to avoid liability for using copyright works and other subject matter. Directive (EU) 2019/790 particularly regulates that this shall not be possible any more. ${ }^{17}$ The described activity of online content-sharing platforms shall be allowed only if they make best efforts to obtain licences from the right owners or remove or disable the access to the content for which they did not obtain a licence.

The rights of reproduction, communication to the public or making available to the public are engaged in all activities in which cultural heritage institutions make digital copies of works and other subject matter contained in their collections and present them to the public via the internet. So, cultural heritage institutions may not act freely and digitalise their collections' content and enable access to their collections if they have not previously acquired a licence to do so. Acquiring licences

13 Art. 15 of WPPT regulates the right to remuneration for commercial phonograms. The agreed statement concerning this article makes it possible to provide for more extensive protection based on exclusive right. For example, the Croatian Copyright and Related Rights Act gives performers exclusive rights in all performances fixed in commercial and non-commercial phonograms.

14 It is regulated in Art. 3 para 1 of Directive 2001/29/EZ for authors and in para 2 for performers, phonogram producers, film producers and broadcasters. These provisions were drafted by taking into consideration previously internationally-accepted definitions from Art. 8 of WCT for authors and Arts. 10 and 14 for performers and phonogram producers, respectively.

15 See Art. 17 of Directive (EU) 2019/790.

16 See Art. 14 of European Parliament and Council Directive 2000/31/EC on certain legal aspects of information society services, in particular electronic commerce, in the Internal Market [2000] OJ L 178/1 (hereinafter: Directive 2000/31/EC).

17 See Art.17 para 3 of Directive (EU) 2019/790. 
is costly and practically impossible for all situations since many right owners are unwilling to issue licences to cultural heritage institutions to present the protected content online. Therefore, because of their public mission and the public interest involved, there are situations where the legal framework allows cultural heritage institutions to do this even without acquiring a licence. These are called exceptions and limitations to copyright and related rights. These situations are well balanced and relate only to certain special cases, which will not be unreasonably detrimental to the right owners' legitimate interests. ${ }^{18}$ It will be analysed supra which exceptions and limitations already exist in the European acquis that are directed to simplify the digitalisation of cultural heritage and provide access to digitised content.

The COVID-19 pandemic situation has pushed cultural heritage institutions towards presenting the content of their collection online more than before since they were or still are closed in lockdowns. Even when they are not in lockdown, physical access to libraries, museums, archives and other cultural heritage institutions is still restricted. So, digital presentation of their content online seems to be a much more important method of communication tothe public and enabling consumption of the content from their collections than before the pandemic. Nevertheless, such a health threat situation is not regulated as the cause for applying any of the existing exceptions and limitations of copyright.

\section{EXCEPTIONS AND LIMITATIONS FOR CULTURAL HERITAGE INSTITUTIONS}

Cultural heritage institutions' relationship to copyright and related rights is regulated in Directive 2001/29/EC, Directive 2012/28/EZ and Directive (EU) $2019 / 790$ through several exceptions and limitations. Their initial, and primary, design was to enable the preservation of works and other protected subject matter contained in cultural heritage institutions' collections. At the same time that users' habits in the digital market have changed, cultural heritage institutions' public mission has also changed and transformed into enabling access to their digitised collections online. Following thisdevelopment of users' habits and the expansion of the digital market, the cultural heritage institutions' public mission has been, over time, supported by more exceptions and limitations to copyright and related rights.

18 See Art. 5. para 5 of Directive 2001/29/EC. This is called the three-step-test. There has been discussion on whether this text is binding only for the legislator or also for the courts. For analysis of this question see: van Eechoud, M. et.al., Harmonizing European Copyright Law: The Challenges of Better Lawmaking, Information Law Series 19, Kluwer Law International, Alphen aan den Rijn, 2009, pp. 113, 114. 


\subsection{Directive 2001/29/EC}

The first exception, regulated in Directive 2001/29/EC, enables publicly accessible libraries, museums and archives to make "specific acts of reproduction" which are not for direct or indirect economic or commercial advantage. ${ }^{19}$ By applying this exception, cultural heritage institutions could digitise protected works and other subject matter without making them available on the internet. Simultaneously, another exception was regulated, which gave the same institutions the ability to enable individual users to use digitised content on specially-dedicated terminals on their premises. This is possible for research and private study purposes, as a limitation to the right of reproduction and communication to the public, including making available to the public. ${ }^{20}$ Directive 2001/29/EC provides one more exception for cultural heritage institutions: broadcasting organisations' official archives. The ephemeral recordings made by such institutions may be preserved if they have exceptional documentary character, even if the broadcasting organisation has only acquired a licence for broadcasting and not for reproduction. ${ }^{21}$ Use in order to advertise the public exhibition or sale of artistic work, to the extent necessary to promote the respective event and excluding any other commercial use, is also regulated as an exception to copyright. ${ }^{22}$

Directive 2001/29/EC was designed, among other things, to regulate the right of making available to the public as an exclusive right for on-demand uses on the in-

19 Art. 5 para 2 c) of Directive 2001/29/EC. A specific act of reproduction, for example for preservation, excludes the possibility of wide-range digitalisation. See also: Axhamn, J., Guibault, L., Cross-border extended collective licensing: a solution to online dissemination of Europe's cultural heritage? Final report prepared for EuropeanaConnect, Universiteit van Amsterdam, 2011, [https://www.ivir.nl/publicaties/ download/ECL_Europeana_final_report092011.pdf], Accessed 03 April 2021, pp. 15-17. This exception was not mandatory for the Member States and therefore its implementation was not consistent. Dusollier, S., The 2019 Directive on Copyright in the Digital Single Market: Some progress, a few bad choices, and an overall failed ambition, Common Market Law Review, Vol. 57, No. 4, 2020, p. 993.

20 Art. 5 para 2 n) of Directive 2001/29/EC. This exemption should equate to use "on the spot" and is not designed for gathering a new public online. See: Axhamn, J., Guibault, L., op. cit., pp. 17-19. Nevertheless, this exception was not consistently implemented throughout the European Union and was too narrow. Dusollier ibid., p. 991. The Court of Justice of the European Union ruled that libraries have "the right to digitise" and to give access to this digitised content on the terminals in their premises. Nevertheless, it ruled that members of the public may not store the digitised copies on their USB devices or to print them out, unless private copy exception is regulated in the legislation of the respective Member States. This means that the exceptions in Art. 5 paras 2 c) and 2 n) of Directive 2001/29/EC do not encompass private copying, which is regulated in Art. 5. paras 2 a) and b) of the same directive. See also Panezi, A., The Role of Judges in Deciding the Future of Digital Libraries, Global Jurist, Volume 17, Issue 1, 20150025, 2017, pp. x-xi; Case 117/13, Eugen Ulmer [2014] ECLI:EU:C:2014:2196.

21 Art. 5 para 2 d) of Directive 2001/29/EC. Some claim that this might be a basis for a limitation on non-interactive streaming services. See Online music distributions - study 126, 127.

22 Art. 5 para 2 j) of Directive 2001/29/EC. 
ternet, within the concept of communication to the public. It was popularly called the "Info-Society Directive". Its principal aim was to regulate the content of copyright and related rights for new digital uses and exceptions and limitations thereto. Nevertheless, it soon became apparent that this directive had not envisaged all the challenges of the new ways of consuming the protected content. This particularly applied to cultural heritage institutions' public mission in the digital world. It was recognised that authors and other right owners, such as publishers and producers, have interests in excercising exclusive rights acquired by legal transactions or directly by the law. But at the same time, providing access to knowledge, particularly for non-commercial and private uses, for research and individual education, through cultural heritage institutions' digitised collections represents a constant public interest. The Europeana project, ${ }^{23}$ in particular, pushed the idea of providing more exceptions and limitations to copyright and related rights to benefit the cultural heritage institutions' mission toprovide access to digitalised European cultural heritage.

\subsection{Directive 2012/28/EU}

The European Union is constantly trying to find the balancing point where the protection of exclusive copyright and related rights should stop, and free reproduction and making available to the public should start, in order that the cultural heritage institutions' public mission may be fulfilled. ${ }^{24}$ An important window was found in the specific position of so-called "orphan works", to which Directive 2012/28/EU ${ }^{25}$ is dedicated. ${ }^{26}$ Orphan works are works and phonograms that are still under protection, ${ }^{27}$ but whose authors or other right owners (i.e. author's heirs, performers, publishers or producers or their successors in title) are not

${ }_{23}$ [https://www.europeana.eu/en/ ], accessed 08 April 2021. See also Communication from the Commission to the European Parliament, the Council, the European Economic and Social Committee and the Committee of the Regions; Europeana - next steps, Brussels, 28.8.2009 COM(2009) 440 final.

24 There are many policy documents and initiatives issued at the European level which “...all insist on the need to foster long-term digital preservation of cultural material, in full respect of international and European copyright laws"; Dusollier, op. cit., note 19, p. 992.

25 European Parliament and Council Directive 2012/28/EU on certain permitted uses of orphan works [2012] OJ L 299/5 (hereinafter: Directive 2012/28/EU).

26 For example, there are estimates that orphan works constitute about $40 \%$ of the collection of the British Library and 22\% of the Carnegie Mellon University Libraries. Bingbin L., The Orphan Works Copyright Issue: Suggestions for International Response, Journal of the Copyright Society of the USA, Vol. 60, No. 3, pp. 256, 257.

27 In particular, published books, magazines, newspapers, journals and other writings, cinematographic or audiovisual works and phonograms and works or other protected subject matter embedded or incorporated in them. For details see Art. 1 paras 2 to 4 of Directive 2012/28/EU. 
known or are known but cannot be found despite diligent search. ${ }^{28}$ Because their authors and other right owners cannot be identified or located, such works are called orphan works. ${ }^{29}$ Diligent search is the standard that needs to be established by cultural heritage institutions based on the provisions of Directive 2012/28/ EU. ${ }^{30}$ It should not require more effort in time and costs than would be reasonable for this purpose. Orphan works are subject to special exceptions regulated in Directive $2012 / 28 / \mathrm{EU}^{31}$ if they are contained in the collections of public heritage institutions. $^{32}$

Within the scope of the application of orphan works' exception, cultural heritage institutions include publicly accessible libraries, educational establishments and museums, archives, film or audio heritage institutions, and public-service broadcasting organisations. ${ }^{33}$ They may reproduce orphan works from their collections, that is digitise them, without the copyright owner's authorisation. The reproduction exception may also be used for cataloguing, indexing, preservation and restoration. Moreover, cultural heritage institutions may offer orphan works in a

28 Diligent search is defined in Art. 3 of Directive 2012/28/EU and sources that should be included in a diligent search are listed in the annexe to this directive. For detailed analysis of diligent search as a standard see in: Schroff, S.; Favale, M.; Bertoni, A., The Impossible Quest-Problems with Diligent Search for Orphan Works, IIC - International Review of Intellectual Property and Competition Law volume 48, 2017, pp. 286-304. Diligent search may incur high costs, therefore the full potential of orphan works' exception may not be achieved. Some authors suggest a crowdsourcing platform as a solution to this challenge. See: Borghi, M.; Erickson, K.; Favale, M., With Enough Eyeballs All Searches Are Diligent: Mobilizing the Crowd in Copyright Clearance for Mass Digitization, Chicago-Kent - Journal of Intellectual Property, Vol. 16, Issue 1, 2016, pp. 161-165.

29 A definition of orphan works is given in Art. 2. of Directive 2012/28/EU.

30 For an overview of the development of orphan works regulation, which culminated in Directive 2012/28/EU and its implementation in France and the Netherlands, see Copyright, and the Regulation of Orphan Works: A comparative review of seven jurisdictions and a rights clearance simulation pp.24-31.

31 Some emphasise that Directive 2012/28/EU is not a full solution for orphan works since it covers only public interest solutions and does not address the authorised uses of orphan works by other persons and entities, for purposes other than public interests. Bingbin, op. cit., note 26, p. 273.

32 The European Union's approach to orphan works is concentrated on cultural heritage institutions. Nevertheless, orphan works are involved in uses in the private sector, outside the public interest. There are different legal solutions for the resolution of this problem worldwide. See: Bzhar, A.; Al-Salihi, K. H., Analysis of the proposed solutions for the use of orphan works across the world, The Journal of World Intellectual Property, Vol. 23, Issue 3-4, pp. 350-374. In the Member States of the European Union, extended collective licences partly resolve the problem of representation of right owners who cannot be located or are not known. The issue of unclaimed royalties is regulated in rec. 29 of the Preamble and in Art. 8 para 5 subparas b) and e) and in Art. 13 paras 2 to 6 of European Parliament and Council Directive 2014/26/EU on collective management of copyright and related rights and multi-territorial licensing of rights in musical works for online use in the internal market [2014] OJ L 84/72.

33 Art. 1 para 1 of Directive 2012/28/EC. The exceptions of orphan works from the archives of broadcasting organisations are limited to the ones produced by the 31 December 2002. 
digitised form to the public for interactive access. Therefore, the law shall permit cultural heritage institutions to use the exception to the right of making available to the public. Preservation, restoration, and provision of access to the public of orphan works from their collections are qualified as cultural heritage institutions' public mission activities. ${ }^{34}$

\subsection{Directive (EU) $2019 / 790$}

Cultural heritage institutions were regualted for the first time under this expression in Directive (EU) 2019/790. They comprise publicly accessible libraries or museums, archives, and film or audio heritage institutions. This definition also includes national libraries and archives, and - as far as their archives and publicly accessible libraries are concerned - educational establishments, research organisations and public sector broadcasting organisations. ${ }^{35}$ Their permanent collections contain diverse content protected by copyright and related rights. Comparison of the definition of cultural heritage institutions from Directive (EU) 2019/790 with Directive 2012/28/EU and Directive 2001/29/EC suggests that they overlap.

The orphan works' exception to copyright and related rights paved the way for the next legislative initiative with the same purpose, brought into existence in Directive (EU) 2019/790. There, cultural heritage institutions are supplied with additional opportunities to ensure wider access to their collections on the internet. This was achieved through a special regime applicable to out-of-commerce works and other subject matter. ${ }^{36}$ This regime puts in first place the extended collective management of out-of-commerce works and other subject matter. Collective management organisation, which is sufficiently representative for the respective type of works or other subject matter and guarantees the same treatment for all respective right owners, shall be entitled to issue licences for out-of-commerce works and other subject matter, even if not all respective right owners have mandated it to do so. This licence may cover exclusive rights of reproduction, distribu-

34 Exceptions to the right of reproduction and right of making available as defined in Arts. 2 and 3 of Directive 2001/29/EC are regulated in Art. 6 of Directive 2012/28/EU. See in detail: Stamatoudi, I.; Torremans, P., EU Copyright Law - A Commentary, Edward Elgar, Cheltenham, UK + Northampton, MA, USA, 2014, pp. 684-686.

35 Art. 2 subpara 3 and Rec. 13 of the preamble of Directive (EU) 2019/790.

36 Out-of-commerce works and other protected subject matter are not available through customary channels of commerce after a reasonable effort to try to determine their availability to the public. A definition is given in Art. 8 para 5 of Directive (EU) 2019/790. It seems that the "reasonable effort" which is given as the standard for out-of-commerce works is more flexible and less stringent that the "diligent search" posed by Directive 2012/28/EU for orphan works. Therefore, when there is the possibility of a choice between the status of orphan work and out-of-commerce work, it seems more convenient to rely on the out-of-commerce scheme. See also: Dusollier, op. cit., note 19, p. 994. 
tion and communication to the public or making available to the public. It shall be non-exclusive for non-commercial purposes and shall be issued only to cultural heritage institutions. Where there is no collective management organisation for specific types of work and other subject matter, Directive (EU) 2019/790 envisages a specific exception to the exclusive right of reproduction and communication to the public or making available to the public, for cultural heritage institutions. ${ }^{37}$ Considering that this exception relates to all types of works and subject matter of related rights, it is expected that out-of-commerce exceptions shall apply in situations where it is not usual to administer rights collectively. Collective management organisations usually exist in the music and audiovisual field and, in some countries, for visual arts. Data on out-of-commerce works shall be distributed to the European Union Intellectual Property Office, which is obliged to publish it through its web portal dedicated to out-of-commerce works and other subject matter. ${ }^{38}$ And finally, all right owners shall have the right to exclude their works or other subject matter from the out-of-commerce regime, either in general or in specific cases, at any time, easily and effectively, including after the conclusion of a licence or after the beginning of the use.

It was emphasised in the preamble of Directive (EU) 2019/790 that the exceptions and limitations regulated in Directive 2001/29/EZ are not sufficient for current developments of the Digital Single Market. In particular, the exceptions and limitations need to be widened concerning cross-border digital uses and cultural heritage preservation. ${ }^{39}$ Therefore, another mandatory exception to the exclusive right of reproduction for all types of works and subject matter protected by related rights permanently contained in the collections of cultural heritage institutions is provided, with the purpose of their preservation. They are allowed to make copies thereof, in any format or medium, for such a purpose. ${ }^{40}$ This is an important step forward for cultural heritage institutions, since in Directive 2001/29/EC, the exception for "some acts of reproduction" was not mandatory.

Finally, Directive (EU) 2019/790 regulates another exception to the exclusive right of reproduction and extraction of the reproduced parts for all works and subject matter of related rights, including computer programs and original and sui generis databases. Reproductions and extractions are allowed for text and data mining for scientific research, from works and other subject matter to which cul-

\footnotetext{
37 Detailed regulation for out-of-commerce works is provided in Art. 8 of Directive (EU) 2019/790.

38 Detailed regulation see in Art. 10 of Directive (EU) 2019/790.

39 Rec. 5 of the Preamble of Directive (EU) 2019/790.

40 Art. 6 of Directive (EU) 2019/790.
} 
tural heritage institutions have lawful access. ${ }^{41}$ No contractual arrangement may override this exception. ${ }^{42}$ Text and data mining results may be stored with the appropriate security level and retained for scientific research.

\section{RE-USE OF PUBLIC SECTOR INFORMATION FROM CULTURAL HERITAGE INSTITUTIONS}

Directive (EU) 2019/1024 $4^{43}$ regulates open data and the re-use of public sector information. The idea of this directive is to affirm the re-use (for mostly economic purposes $)^{44}$ of data produced in the public sector, to encourage innovation, create new values, new digital products, new applications, and to create an incentivising environment for the development of start-up companies and small and medium enterprises which should be able to re-use public sector data within new technologies in the production of their new digital products. The aim is also to adapt the legal environment to further develop machine learning, artificial intelligence, ${ }^{45}$ and the internet of things. ${ }^{46}$ Re-use of data is also connected with big data, which is defined as "the collection and aggregation of large masses of available data from a wide variety of different sources and its analysis, largely in the form of correlation, pattern-recognition, and predictive analysis." ${ }^{47}$ Big data initiatives are usually linked to the openness of public sector data. ${ }^{48}$

41 This exception also relates to research organisations such as universities and scientific institutions. See Art. 3 of Directive (EU) 2019/790. Lawful access means that there is some contractual arrangement between right owners and cultural heritage institutions, such as subscriptions, or that access is based on an open licence or that the content is freely available on the internet. See rec. 14 from the preamble of Directive (EU) 2019/790.

42 Some examples of this exception might be “...newspapers' archives by linguists to identify the evolution of some language patterns, or to all scientific articles published in one field to analyse gender distribution in authorship or quotations"; Dusollier, op. cit., note 19, p. 985.

43 European Parliament and Council Directive 2019/1024 on open data and the re-use of public sector information [2019] OJ L 172/56 (hereinafter: Directive (EU) 2019/1024).

44 Dalla Core, L., Towards Open Data Across the Pond, in: van Loenen, B.; Vancauwenberghe, G.; Crompvoets, J. (eds.) Open Data Exposed - Information Technology and Law Series, IT\&LAW 30, Springer, 2018, pp. 11-32, pp. 16, 22.

45 G Spindler, G., Copyright Law and Artificial Intelligence, IIC - International Review of Intellectual Property and Competition Law, Vol. 50, 2019, p. 1050.

46 Otero, B. G., Evaluating the EC Private Data Sharing Principles - Setting a Mantra for Artificial Intelligence Nirvana?, JIPITEC - Journal of Intellectual Property, Information Technology and E-Commerce Law, Vol. 10, No. 1, 2019, p. 68.

47 de Hert, P.; Sajfert, J., Regulating Big Data In and Out of the Data Protection Policy Field: Two Scenarios of Post-GDPR Law-Making and the Actor Perspective, European Data Protection Law Review, Vol. 3, No. 5, 2019, p. 338; Forgo, N.; Hinold, S.; Schutze, B., The Principle of Purpose Limitation and Big Data, New Technology, Big Data and the Law, Perspectives in Law, Business and Innovation, Springer Nature Singapore, 2017, pp. 17-42.

48 de Hert; Sajfert, op. cit., note 44, p. 347. 
Re-use means use that differs from the initial purposes for which the data were created. The idea is to ensure that information once created for some public purpose or in providing services in the general interest, whereby this creation or collection was funded from public resources, is eligible for any other commercial or non-commercial purpose, subject to some necessary restrictions. Data - documents which might be under copyright or related rights protection in the collections of cultural heritage institutions (public libraries, archives, and museums) - also fall within the scope of "public sector information" or "documents" to which the re-use obligation applies. ${ }^{49}$ Cultural heritage collections and related metadata are recognised to have huge potential for innovative re-use, particularly in learning and tourism. ${ }^{50}$ Therefore, cultural heritage institutions should also provide their data for re-use, but not automatically; they can decide whether to give some sets of data for re-use if they hold the copyright or related rights on such data. On the other hand, in order to preserve their public mission and make their activities sustainable, when providing data for re-use, cultural heritage institutions have the right to charge above marginal costs and require, within the price charged, a reasonable return on investment. Market prices should be taken into account when calculating the latter. ${ }^{51}$

Documents on which third parties hold the copyright or related rights are generally not subject to the obligation of re-use. ${ }^{52}$ This means that the documents and metadata under copyright and related rights protection of third parties shall not be subject to re-use through cultural heritage institutions. Therefore, Directive (EU) 2019/1024 should not be considered as the legal source for exceptions and limitations to copyright and related rights. It only regulates how public sector bodies, including cultural heritage institutions, should exercise their own copyright and related rights. Within this context, it seems that the content that cultural heritage institutions may use under exceptions and limitations from Directive 2001/29/ EC, Directive 2012/28/EU and Directive (EU) 2019/790 should still be considered as third party copyright. If some exception or limitation is provided only for non-commercial purposes or only for cultural heritage institutions, re-use obligation should not indirectly result in re-use for other purposes.

On the other hand, Directive (EU) 2019/1024 encourages cultural heritage institutions to digitise the content from their collections that is not protected by third party copyright and related rights and to provide it for re-use. It also encourages

\footnotetext{
49 It comes from Art. 1, para 2 (i) of Directive (EU) 2019/1024.

50 Rec 65 of Preamble of Directive (EU) 2019/1024.

51 See Rec 38 of Preamble of Directive (EU) 2019/1024.

52 Rec. 54, 55 of Preamble of Directive (EU) 2019/1024.
} 
cultural heritage institutions to make contractual arrangements with private sector partners, which may invest in the digitalisation of their collections in the public domain and, consequently, have the exclusive right to re-use this content. Nevertheless, this exclusive right of re-use should not exceed ten years: given as the milestone for recouping investments made in digitalisation. After this exclusivity period expires, the data should be given back to the cultural heritage institution for further exploitation. ${ }^{53}$

So, it is clear that Directive (EU) 2019/1024 does not interfere with third party copyright and related rights in works and other subject matter contained in the collections of cultural heritage institutions. They remain untouched by this directive. It does not regulate any new exception or limitation towards third party copyright and related rights. On the other hand, it encourages cultural heritage institutions to give up their copyright and related rights (if existing) on their digitised collections and provide them for re-use. ${ }^{54}$ Particularly, Directive (EU) 2019/1024 regulates that cultural heritage institutions, as all other public sector bodies, shall not exercise their sui generis database right on their digitised collections to prevent re-use. ${ }^{55}$ At the same time, should they provide their documents (data in digitised form), with metadata, for re-use for commercial or non-commercial purposes, they can charge above marginal costs and claim a reasonable return of investments under market prices. This gives them the necessary resources to ensure their sustainability, while still serving the public mission.

\section{POSSIBLE IDEAS FOR FUTURE DEVELOPMENTS}

It has been shown here how exclusive copyright and related rights interfere with cultural heritage institutions' public mission. The COVID-19 pandemic situation has triggered some new developments in thinking about this relationship because the cultural heritage institutions' public mission has been even more emphasised. The demand for accessibility of the digitised content of their collections has grown rapidly. Moreover, some eminent authorities predict that similar situations in which some new pandemics threaten public health will occur in the future. ${ }^{56}$ Due to the COVID-19 pandemic situation, the demand for digitalisation and online accessibility of cultural heritage institutions' collections will certainly grow

53 Rec. 49 of Preamble of Diretive (EU) 2019/1024.

54 See also: Keller, P.; Margoni, T.; Rybicka, K.; Tarkowski, A., Re-Use of Public Sector Information in Cultural Heritage Institutions, The Journal of Open Law, Technology \& Society, Vol. 6, No. 1, 2014, p. 8.

55 Art. 1 para 6 of Directive (EU) 2019/1024.

56 Gates, B., Wir sind auf die nächste Pandemie nicht vorbereitet, [https://www.sueddeutsche.de/politik/ coronavirus-pandemie-bill-gates-impfstoff-interview-1.5187121?reduced=true ], Accessed 11 April 2021. 
more quickly than previously envisaged. The new circumstances and new habits will persist after the pandemic is over. Therefore, maybe a new balance between copyright and related rights and cultural heritage institutions should be designed.

This requires thinking in two directions. The first is related to the general issue of mass digitisation, and the second relates to digitalisation and making available online in extreme situations. The first direction might lead to compulsory licences. In situations where there is a prevailing public interest in mass digitisation of cultural heritage collections and providing online access to digitised content, the compulsory licence might be the solution. States, through their ministries of culture, might issue compulsory licences, at the request of cultural heritage institutions. A compulsory licence should be issued on the payment of a licencing fee covered from the state budget. This model should refer only to non-commercial uses for reproduction and making available to the public of digitised content.

The second direction might go towards a new exemption to copyright and related rights that would benefit cultural heritage institutions where the possibility of physical access is denied or restricted for some prevailing public interest, such as preservation of public health. This exemption would enable cultural heritage institutions to digitalise and provide access to digitised content despite the third parties' copyright and related rights. This exemption should be conditional and limited in time. Digitisation and making available to the public might be allowed without the right owner's permission but subject to payment of equitable remuneration.

Both models should refer only to non-commercial uses and should be regulated at the European level to ensure the consistency of the offer on the Digital Single Market.

\section{CONCLUSION}

The COVID-19 pandemic has made a tremendous change in consumers' habits worldwide and influenced patterns of perception and consumption of cultural heritage. During lockdowns and restricted access to cultural heritage institutions, many consumers reached for the digitised content of their collections. The institutions demonstrated their ability to adapt swiftly. and offered their collections digitally where possible, taking into consideration third party copyright and related rights. As a matter of course, they are obliged to respect copyright and related rights in works and other subject matter permanently contained in their collections. At the same time, there are exemptions and limitations for preserving cultural heritage, digitisation and access to orphan and out-of-commerce works 
and other subject matter, and text and data mining for research purposes. Cultural heritage institutions are also encouraged to make available content on which they hold copyright and related rights for re-use and are not allowed to exercise their sui generis database rights in their digitised collections.

Still, it seems that the existing legal framework which regulates the conflict between the interest of protecting copyright and related rights and providing the public mission of cultural heritage institutions regulated in Directive 2001/29/EC, Directive 2012/28/EU, Directive (EU) 2019/790 and Directive (EU) 2019/1024 is not enough for them to fulfil their public mission and for extreme situations such as the COVID-19 pandemic. Therefore, copyright and its related rights legal framework need more flexibility.

Two options are offered here to start rethinking the balance. The first option would go towards compulsory licences, which may contribute to mass digitisation. The second goes towards new exceptions and limitations to copyright and related rights for extreme situations. Both options are adapted to the prevailing public interest over the interest of copyright and related rights owners. This refers only to the authorisation for digitisation and online access. The right to equitable remuneration for authors and other right owners should not be endangered.

\section{REFERENCES}

\section{BOOKS AND ARTICLES}

1. Bingbin L., The Orphan Works Copyright Issue: Suggestions for International Response, Journal of the Copyright Society of the USA, Vol. 60 No. 3, pp. 255-284

2. Borghi, M.; Erickson, K.; Favale, M., With Enough Eyeballs All Searches Are Diligent: Mobilizing the Crowd in Copyright Clearance for Mass Digitization, Chicago-Kent - Journal of Intellectual Property, Vol. 16, Issue 1, 2016, pp. 136 - 166

3. Bzhar, A.; Al-Salihi, K. H., Analysis of the proposed solutions for the use of orphan works across the world, The Journal of World Intellectual Property, Volume 23, Issue 3-4, pp. 350-374

4. Dalla Core, L., Towards Open Data Across the Pond, in: van Loenen, B.; Vancauwenberghe, G.; Crompvoets, J. (eds.) Open Data Exposed - Information Technology and Law Series, IT\&LAW 30, Springer, 2018, p. 11-32

5. de Hert, P.; Sajfert, J., Regulating Big Data In and Out of the Data Protection Policy Field: Two Scenarios of Post-GDPR Law-Making and the Actor Perspective, European Data Protection Law Review, Vol. 3, No. 5, 2019, p. 338-351

6. Dusollier, S., A manifesto for an e-lending limitation in copyright, JIPITEC - Journal of Intellectual Property, Information Technology and E-Commerce Law, Vol. 5, No. 3, 2014, pp. $1-23$ 
7. Dusollier, S., The 2019 Directive on Copyright in the Digital Single Market: Some progress, a few bad choices, and an overall failed ambition, Common Market Law Review, vol. 57, no. 4, 2020, pp. 979-1030

8. Forgo, N.; Hinold, S.; Schutze, B., The Principle of Purpose Limitation and Big Data, New Technology, Big Data and the Law, Perspectives in Law, Business and Innovation, Springer Nature Singapore, 2017, pp. 17-42

9. Keller, P.; Margoni, T.; Rybicka, K.; Tarkowski, A., Re-Use of Public Sector Information in Cultural Heritage Institutions, The Journal of Open Law, Technology \& Society, Vol. 6, No. 1, 2014, pp. 1-10

10. Leistner, M., Copyright at the interface between EU law and national law: definition of "work" and "right of communication to the public, Journal of Intellectual Property Law \& Practice, Vol. 10, No. 8, 2015, pp. 626-637

11. Otero, B. G., Evaluating the EC Private Data Sharing Principles - Setting a Mantra for Artificial Intelligence Nirvana?, JIPITEC - Journal of Intellectual Property, Information Technology and E-Commerce Law, Vol. 10, No. 1, 2019, pp. 66-84

12. Panezi, A., The Role of Judges in Deciding the Future of Digital Libraries, Global Jurist, Volume 17, Issue 1, 20150025, 2017, pp. i-xxii

13. Quintais, J. P., Untangling the hyperlinking web: In search of the online right of communication to the public, The Journal of World Intellectual Property, Vol. 21, Issue 5-6, 2018, pp. 385-420

14. Schroff, S.; Favale, M.; Bertoni, A., The Impossible Quest-Problems with Diligent Search for Orphan Works, IIC - International Review of Intellectual Property and Competition Law volume 48, 2017, pp. 286-304

15. Spindler, G., Copyright Law and Artificial Intelligence, IIC - International Review of Intellectual Property and Competition Law, Vol. 50, 2019, p. 1049-1051

16. Stamatoudi, I.; Torremans, P., EU Copyright Law - A Commentary, Edward Elgar, Cheltenham, UK + Northampton, MA, USA, 2014

17. van Eechoud, M. et.al., Harmonizing European Copyright Law: The Challenges of Better Lawmaking, Information Law Series 19, Kluwer Law International, Alphen aan den Rijn: 2009, p. $113-114$

18. Xalabarder, R., The Role of the CJEU in Harmonizing EU Copyright Law, IIC - International Review of Intellectual Property and Competition Law volume 47, 2016., pp. 635-639

\section{EU LAW}

1. European Parliament and Council Directive 2006/115/EC on rental right and lending right and on certain rights related to copyright in the field of intellectual property [2006] OJ L $376 / 28$

2. Council Directive $2001 / 29 /$ EC on the harmonisation of certain aspects of copyright and related rights in the information society [2001] OJ L 167/10

3. European Parliament and Council Directive 2019/790 on copyright and related rights in the Digital Single Market and amending Directives 96/9/EC and 2001/29/EC [2019] OJ L 130/92 
4. European Parliament and Council Directive 2000/31/EC on certain legal aspects of information society services, in particular electronic commerce, in the Internal Market [2000] OJ L 178/1

5. European Parliament and Council Directive 2012/28/EU on certain permitted uses of orphan works [2012] OJ L 299/5

6. European Parliament and Council Directive 2014/26/EU on collective management of copyright and related rights and multi-territorial licensing of rights in musical works for online use in the internal market [2014] OJ L 84/72

7. European Parliament and Council Directive 2019/1024 on open data and the re-use of public sector information [2019] OJ L 172/56

\section{INTERNATIONAL LAW}

1. WIPO Copyright Treaty (WCT) (1996) [https://www.wipo.int/treaties/en/ip/wct], Accessed 31 March 2021

2. WIPO Performances and Phonograms Treaty (WPPT) (1996) [https://www.wipo.int/treaties/en/ip/wppt/], Accessed 31 March 2021

\section{LIST OF NATIONAL REGULATIONS, ACTS AND COURT DECISIONS}

1. Case 117/13, Eugen Ulmer [2014] ECLI:EU:C:2014:2196

2. Case C-174/15 Vereniging Openbare Bibliotheken [2016] ECLI:EU:C:2016:856

3. Croatian Copyright and Related Rights Act, Official Gazette, No. 167/03, 79/07, 80/11, $125 / 11,141 / 13,127 / 14,62 / 17,96 / 18$

4. Urheberrechtsgesetz vom 9. September 1965 (BGBl. I S. 1273), das zuletzt durch Artikel 4 des Gesetzes vom 26. November 2020 (BGBl. I S. 2568) geändert worden ist (Zuletzt geändert durch Art. 4 G v. 26.11.2020 I 2568), [https://www.gesetze-im-internet.de/urhg/index.html\#BJNR012730965BJNE022614360], Accessed 02 April 2021

\section{WEBSITE REFERENCES}

1. Axhamn, J., Guibault, L., Cross-border extended collective licensing: a solution to online dissemination of Europe's cultural heritage? Final report prepared for EuropeanaConnect, Universiteit van Amsterdam, 2011, [https://www.ivir.nl/publicaties/download/ECL_Europeana_final_report092011.pdf], Accessed 03 April 2021

2. Europa Nostra: COVID-19 \& BEYOND, Challenges and Opportunities for Cultural Heritage, October 2020 [https://www.europanostra.org/wp-content/uploads/2020/10/20201014_COVID19_Consultation-Paper_EN.pdf], Accessed 31 March 2021

3. Gates, B., Wir sind auf die nächste Pandemie nicht vorbereitet, [https://www.sueddeutsche. de/politik/coronavirus-pandemie-bill-gates-impfstoff-interview-1.5187121? reduced=true ], Accessed 11 April 2021

4. UNESCO: Culture \& Covid-19, Impact and Response Tracker - special issue, 3 July 2020 [https://en.unesco.org/sites/default/files/special_issue_en_culture_covid-19_tracker.pdf], Accessed 31 March 2021 